\title{
José Martí e o liberalismo: a trajetória intelectual de um exilado cubano no México
}

Jorge Eschriqui Vieira Pinto*

Resumo: Este artigo apresenta as análises de José Martí sobre o projeto para a construção de um Estado-Nação elaborado pelos liberais, que é o resultado de um conjunto de ideias que surge e se desenvolve ao longo do século XIX no México. Dessa maneira, o intelectual cubano, desde os seus artigos jornalísticos escritos durante o período em que se exilou nesse país, entre 1875 e 1876, não somente deixou as suas impressões sobre vários aspectos do cotidiano mexicano, mas também refletiu sobre os alcances e os limites do projeto liberal no sentido de transformar essa realidade.

Palavras-chave: Estado-Nação. Liberalismo. México.

\section{Introdução}

Este artigo trata dos escritos produzidos por José Martí entre 1875-1876, período em que se encontrava no México, sendo constituídos por artigos jornalísticos em que o autor, baseado na análise dos vários aspectos do cotidiano mexicano, expressou as suas opiniões sobre o projeto liberal para a construção do Estado-

* Bacharelado e Licenciatura Plena em História pela Universidade de Brasília (UnB). Mestre e Doutor em História pela Universidade Estadual Paulista Júlio de Mesquita Filho (UNESP), campus de Franca - SP. E-mail: jschriqui@pormexico. com. Endereço para correspondência: $3^{a}$ Avenida Bloco 2045 Casa 11 - Núcleo Bandeirante, Brasília, Distrito Federal. CEP 71720-029. 
Nação mexicano e as dificuldades que esse enfrentava diante das circunstâncias históricas.

Os artigos jornalísticos foram escritos para a Revista Universal e El Federalista e estão presentes nas obras completas de José Martí, que se exilou no México durante os anos de 1875-1876, período da chamada República Liberal Restaurada (termo criado pela historiografia tradicional para se referir à retomada do poder pelos liberais após a queda do Império de Maximiliano [1864-1867]).

O objetivo deste artigo é analisar Martí no México, levando-se em conta que, enquanto um viajante que viveu a realidade mexicana, foi influenciado pelo período em que esteve nesse país, principalmente por elementos do projeto nacional do liberalismo mexicano, tais como a questão do nativo, da indústria e do comércio nacional, da valorização da cultura nacional, do caudilhismo, entre outros. Os liberais buscavam,por meio desse projeto, reverter uma cultura política marcada pela presença de elementos percebidos como prejudiciais para a constituição do Estado-Nação ideal,como o descaso da população em relação às eleições, as guerras civis constantes pela disputa de poder, o forte vínculo entre o Estado e a Igreja, o caudilhismo, dentre outros. Desse modo,o projeto do Estado-Nação ideal para os liberais vinha acompanhado pela tentativa de se mudar a ação dos mexicanos frente à política por meio de procedimentos como a busca da pacificação do país, a implantação do modelo federalista com a existência de três poderes,o sufrágio universal, a separação entre Igreja e Estado, o combate ao caudilhismo, o desenvolvimento da educação etc.

\section{Pensar a vida, a obra e o pensamento de José Martí}

Quando se pensa na figura de José Martí, geralmente a ideia que vem à tona é a de um revolucionário convicto que percebe na revolução o único instrumento capaz de propagar a liberdade, a igualdade e a justiça. Seguindo esta linha de pensamento, boa parte da produção historiográfica sobre José Martí concebe-o como um propagador dos ideais de igualdade econômica, racial e social de todos os homens, marcado pela escolha entre duas alternativas, 
isto é, ou parte-se para a revolução como forma de se solucionar os problemas econômicos, raciais, culturais, sociais e políticos, e de se constituir uma realidade alternativa ou se aceita uma situação de jugo diante das desigualdades e das injustiças.

Entre os estudiosos latino-americanos que seguem esta forma de análise histórica está Florestan Fernandes, segundo o qual Martí deixou como exemplo para a posteridade a ideia de que

[...] a revolução não é só um 'produto político’. Ela é também uma realização histórica, à qual o intelectual da Nossa América deve devotar humildemente a sua vida, toda a sua vida! Essa é a maior lição de Martí, homem terno e sonhador, mas um revolucionário implacável (FERNANDES, 1995, p. 57).

Não se pretende com isso entrar no mérito de uma discussão sobre a validade deste tipo de produção historiográfica, pois isso exigiria um levantamento detalhado dele e resultaria na elaboração de outro artigo somente para tal finalidade. O que se busca é o posicionamento deste artigo dentro de uma perspectiva histórica que não enfatiza a figura de Martí como herói, apóstolo, profeta, mártir ou guia revolucionário, mas que procura compreender o seu pensamento de forma mais aprofundada. Este aprofundamento ocorre com o entendimento do ideário de Martí a partir da análise do processo histórico dentro do qual ele está inserido, ou seja, da conexão entre ambos. Tal conexão torna o pensamento do autor inseparável do contexto histórico. O contexto que apresenta várias dimensões, que vão desde o contexto discursivo (preocupado com a dinâmica assumida pelos escritos de Martí), passando pelo contexto intelectual (a influência das ideias em vigência no seu pensamento) e atingindo o contexto comunicacional (referente às ideias socialmente sancionadas). De acordo com Maria Alice Rezende de Carvalho, no estudo do pensamento de um intelectual, deve-se considerar o contexto em suas variadas dimensões:

Há o contexto discursivo, referido à dinâmica da obra de um autor; o contexto intelectual, no qual a sua obra se expõe ao diálogo com as ideias em circulação; o contexto 
comunicacional mais amplo, do qual participam diferentes enunciados socialmente sancionados e recursos mediatos diversos. (CARVALHO, 1998, p. 15).

Além disso, a relação entre as ideias e o contexto deve ser considerada como uma relação em que ao mesmo tempo em que as ideias são produzidas em um determinado contexto, aquelas podem vir a ser um instrumento de transformação deste e construir uma nova realidade. Trata-se, enfim, de uma mútua influência. As ideias não têm vida própria. Elas dependem do seu uso, segundo Ângela Alonso, "[...] por parte dos agentes sociais, que as tomam como orientação de sua ação" (ALONSO, 2002, p. 35).

Estes pressupostos teóricos são importantes porque, a partir do estudo dos escritos produzidos por José Martí entre 1875 e 1876, período em que se encontrava no México, nota-se que esse país representou para o intelectual cubano o primeiro contato com um país independente da Hispano-América, podendo perceber os problemas enfrentados que impediam a organização e o desenvolvimento desse país, tais como a marginalização do índio, a corrupção, a dificuldade na implantação de políticas governamentais, a ameaça do expansionismo das potências e outros. Muitos desses aspectos observados por Martí o levariam a refletir sobre as dificuldades que existiram em Cuba no pós-independência no sentido da conformação de um Estado-Nação, uma vez que alguns problemas existentes no México também se faziam presentes em sua terra natal, como a corrupção, a marginalização de grande parte da população (no caso de Cuba, da população negra), a desordem causada pelas guerras internas e outros.

Este artigo apresenta as análises de José Martí sobre o projeto para a construção de um Estado-Nação elaborado pelos liberais, que é o resultado de um conjunto de ideias que surgem e se desenvolvem ao longo do século XIX no México. Dessa maneira, o intelectual cubano, desde os seus artigos jornalísticos escritos durante o período em que se exilou nesse país, entre 1875-1876, não somente deixou as suas impressões sobre vários aspectos do cotidiano mexicano, mas também refletiu sobre os alcances e os limites do projeto liberal no sentido de transformar essa realidade. Esses artigos jornalísticos 
foram publicados na Revista Universal e no El Federalista, estando presentes nas obras completas de José Martí e sendo redigidos na etapa da história mexicana denominada República Liberal Restaurada (1867-1876).

O estudo desses escritos revela que vários pontos presentes no projeto nacional dos liberais, considerados como primordiais para a compreensão dos problemas e constituição de uma nova sociedade baseada nos ideais de ordem e progresso, também observam-se nos artigos de José Martí, tais como a manutenção da ordem, a liberdade de associação e trabalho, a secularização, o desenvolvimento econômico etc. A partir da interpretação da realidade nacional, permeada pela leitura das obras de teóricos considerados como de validade universal, os liberais mexicanos foram elaborando um pensamento que culminou em um projeto de política nacional que visava ao rompimento com um passado colonial, caracterizado pela presença de elementos considerados como prejudiciais para a consolidação de um Estado-Nação forte e desenvolvido. Todavia, esse rompimento não seria um processo fácil nem de curta duração, pois incluía a mudança da cultura política dos mexicanos marcada pelos foros e privilégios, pela apatia política, pela valorização da guerra como fator de resolução de diferenças políticas etc.

\section{Martí no México}

José Martí nasceu em Havana, em 28 de janeiro de 1853, sendo filho dos espanhóis Mariano Martí e Leonor Pérez. Foi um dos mais ativos participantes do programa anticolonialista cubano, o que acabou obrigando-o a se exilar na Europa, no México, na Guatemala, na Venezuela e nos Estados Unidos, onde fundou o Partido Cubano Revolucionário, tornando-se, então, o principal líder pelo movimento de independência de Cuba.

Em 8 de fevereiro de 1875, Martí chegou ao México proveniente da Espanha, para onde foi deportado em 1871, após uma prisão resultante de sua participação no movimento de independência de Cuba, liderado por Carlos Manuel Céspedes e conhecido 
como Grito de Yara, em outubro de 1868. Após a prisão e o exílio de José Martí, o seu pai, Mariano Martí, decidiu tornar-se um participante ativo na luta pela independência, o que lhe causou perseguições por parte do Governo Geral. Isso o obrigou a fugir para o México juntamente com sua família. Ao recebe o comunicado da família sobre a mudança dela para esse país, José Martí decidiu ir ao México para reencontrá-la.

Desembarcando no porto de Veracruz, tomou um trem para a Cidade do México. Por intermédio de sua família, Martí conheceu Manuel Mercado, advogado e, a posteriori, seu melhor amigo, e Pedro Santacilia, ligado ao governo do presidente Sebastián Lerdo de Tejada, que conseguiram um emprego para ele como redator no jornal oficial El Federal.

Em 7 de março de 1875, Martí entrou como cronista para a Revista Universal, publicando um poema dedicado à sua irmã Ana, falecida em 5 de janeiro. Publicou o livro Mes Fils, do escritor francês Victor Hugo, na forma de folhetim, nesse periódico, o que acabou causando impacto entre os letrados mexicanos, aproximando Martí deles. Esses letrados eram em boa parte liberais e de tendência nacionalista e romântica, tendo como bandeira a defesa de uma literatura tipicamente mexicana. Isso contribuiu para que houvesse a identificação de Martí com o liberalismo mexicano e com os temas nacionais.

Foi dentro desse contexto de grande efervescência cultural no México, marcado pela meta de valorização da cultura nacional com o objetivo de se despertar o espírito nacional, que surgiu no período da República Liberal Restaurada (1867-1876) várias revistas literárias e vários periódicos, com destaque para a Revista Universal e El Federalista, dos quais participou José Martí, de associações culturais que chegaram a 124, destacando-se dedicadas a desenvolverem o teatro e protegerem gremialmente os autores, como a Alarcón (1876), da Cidade do México, fundada por José Peón y Contreras, José Martí, Gustavo Baz e Roberto Esteva. Além disso, Martí participou da principal sociedade cultural mexicana, o Liceo Hidalgo.

Martí, em seus artigos para a Revista Universal, demonstrou apoio aos direitos do trabalhador e à sua conscientização. Dessa forma, ele foi designado delegado da sociedade Esperanza de Empleados, 
situada na Cidade do México, no primeiro congresso operário desse país, ocorrido em março de 1876.

No período em que Martí esteve no México (1875-1876), o grupo com o qual ele manteve contato, em sua grande maioria que estava no poder, era o dos liberais. Os liberais mexicanos buscavam constituir um modelo de Estado-Nação a partir de um projeto modernizador que implantaria as reformas visando a um país em que prevalecesse a ordem e o progresso.

O contexto em que Martí viveu no México é caracterizado pela tentativa dos liberais de mudarem uma cultura política marcada pelo descaso da população em relação às eleições, pelas guerras civis constantes pela disputa de poder, pelo forte vínculo entre o Estado e a Igreja etc., por meio da construção de um novo México. Tal tentativa que se estruturava em um projeto de modernização que implantaria as reformas necessárias para a constituição do EstadoNação aspirado pelos liberais. No caso, o Estado seria o agente condutor da modernização, isto é, o instrumento para a organização da vida mexicana. Assim, pode-se dizer que, na sua passagem por esse país, Martí teve a sua trajetória vinculada com a busca de implantar uma nova ordem social por parte do Estado. Em outras palavras, o intelectual cubano analisou em seus artigos para a Revista Universal e El Federalista a cultura política existente no México, ou seja, tanto os valores e o posicionamento da sociedade mexicana diante da política, como também o pensamento e a prática liberal no sentido de mudá-los, percebendo o alcance e o limite de seu projeto.

A nova proposta de cultura política dos liberais mexicanos analisada por Martí visava a uma participação mais ativa de todos os setores da sociedade no sentido de se construir o Estado-Nação ideal nos moldes da ordem e do progresso, o que exigia uma mudança na postura apática e de alienação da maior parte da população com relação à vida política (indiferença), atuando de forma efetiva nos destinos da nação. A partir dos elementos presentes na sociedade mexicana que eram considerados obstáculos ao progresso do país, os liberais elaboraram a sua análise da realidade e elencaram os argumentos no sentido de suplantá-los.

Em novembro de 1876, ocorreu a deposição do governo de Sebastián Lerdo de Tejada, com a sublevação militar do general 
Porfirio Díaz, quando as tropas do governo foram vencidas e a Cidade do México foi ocupada. Vários periódicos deixaram de ser publicados, entre os quais a Revista Universal. Dessa forma, encerrou-se a participação de Martí nesse periódico. O intelectual cubano passou então a escrever artigos para o periódico El Federalista até janeiro de 1877, quando sentiu não ser mais conveniente a sua permanência no México, partindo para a Guatemala.

\section{A República Liberal Restaurada}

O projeto liberal mexicano para a construção do Estado-Nação foi sendo elaborado na medida em que os liberais foram desenvolvendo ao longo do século XIX ideias que buscavam refletir a realidade do país por meio de suas análises e, ao mesmo tempo, através delas, transformar o contexto observado contrário às expectativas de consolidação de uma nação no período pós-independência. $\mathrm{Na}$ proporção em que os acontecimentos foram se sucedendo na história mexicana do século XIX, as ideias liberais foram sendo postas em prática, a partir da percepção daquilo que se compreendia como a realidade vivida, por meio, principalmente, da primeira tentativa de realização de uma reforma liberal em 1833, da Lei Juarez de 1855, da Lei Lerdo de 1856, da Constituição de 1857 e das Leis de Reforma implantadas entre 1859 e 1863. Como afirma Jesús Reys Heroles,

[...] na formação do liberalismo mexicano, processo e resultado são em certa medida inseparáveis e isso consta tanto para a integração das ideias como para a transformação da realidade histórica. O conjunto doutrinal que constitui o liberalismo mexicano não pode ser compreendido se se prescinde do processo mediante o qual as ideias foram surgindo, adaptando-se e encaixando-se entre si ao serem confrontadas com a própria realidade. Por outro lado, isolar esta evolução ideológica do processo histórico político em que se dá, seria formalizar o que é real e desvincular ambos aspectos do meio, do caminho, das etapas da luta com derrotas e vitórias parciais e dos instrumentos nela empregados, perdendo assim 
de vista um dos ângulos mais ricos e instrutivos da formação liberal mexicana. (HEROLES, 1974, p. IX).

Portanto, os liberais mexicanos constituíram ao longo do século XIX até chegar o período da República Liberal Restaurada (1868-1876) o seu projeto para a construção do Estado-Nação, uma interpretação da realidade que, simultaneamente, era uma tentativa de transformá-la, incluindo entre as metas importantes a serem alcançadas nesse sentido a mudança na cultura política que predominava no México. Essa cultura política que, na perspectiva dos liberais, refletia os males existentes na sociedade e constituía um obstáculo à implantação de um Estado-Nação estruturado na ideia de ordem e progresso.

Então, a partir de leituras de teóricos cujas ideias eram vistas como de suposta validade universal, como Benjamin Constant, Benta, Montesquieu e outros, os liberais mexicanos interpretavam a realidade. Entretanto, não se tratava de uma simples importação dessas ideias para o contexto mexicano, mas de uma utilização delas que levava em conta as condições nacionais e a receptividade. Nessa perspectiva, os liberais foram influenciados, principalmente, por Montesquieu e Bentham, pois, segundo Jesús Reyes Heroles,

Montesquieu, vendo as leis naturais conformes com a constituição racional do homem e as positivas como particulares de cada povo e devendo estar de acordo com as condições físicas e sociológicas de cada nação, ou Bentham, sustentando a influência dos tempos e dos lugares em matéria de legislação e proporcionando os princípio que deviam se seguir para a "transplantação das leis e diferentes nações" porque os defeitos destas se manifestam mais quando têm sido transplantadas, eram estímulos evidentes à adaptação (HEROLES, 1974, p. 100).

Esse processo de adaptação das ideias provenientes do exterior não consistia, porém, em uma cópia malfeita ou adaptação de qualquer maneira delas, mas na aplicação das ideias de modo que se tornassem instrumentos para a análise e transformação da realidade 
nacional. Tal compreensão é justificada pela preocupação dos liberais desde a Independência em identificar a ideia de nacionalidade com o pensamento liberal na medida em que este buscava construir um modelo de Estado-Nação a ser implantado no México. Como afirma Jesús Reyes Heroles,

[...] o liberalismo nasce com a nação e esta surge com ele. Há uma coincidência de origem que faz que o liberalismo estruture-se, forme-se, no desenvolvimento mesmo do México, nutrindo-se de seus problemas e tomando características ou modalidades peculiares do desenvolvimento mexicano. (HEROLES, 1974, p. XII).

Outro ponto importante que se deve levar em consideração é que, embora, por questões práticas, separe-se os vários aspectos que constituem a análise liberal da realidade mexicana e o projeto para a construção do Estado-Nação, deve-se entendê-los como integrados uns com os outros. Os vários tópicos que constituíam o pensamento e a ação liberal no México acabaram por ser elementos de explicação e justificativa mutuamente. Partindo da meta de secularização, Jesús Reyes Heroles desenvolve vários questionamentos para demonstrar os vínculos desse aspecto com outros presentes no pensamento liberal mexicano:

[...] a secularização está intimamente conectada com a liberdade de cultos, esta com a liberdade de opinião, que, por sua vez, deriva da liberdade de consciência. E é possível supor a existência da liberdade de consciência sem segurança e liberdade pessoal? São factíveis as liberdades civis sem as políticas? Funcionam estas sem uma divisão de poderes que faça em termos clássicos que o poder detenha ao poder e evite a arbitrariedade? A divisão de poderes opera - e aqui liberalismo e democracia irmanam-se - sem um poder democraticamente representativo? As interrogações podiam se multiplicar: a secularização da sociedade está ligada com as liberdades liberais e estas com as liberdades democráticas. (HEROLES, 1974, p. XV). 
A República Liberal Restaurada iniciou-se em 20 de junho de 1867, quando houve a queda do regime monárquico de Maximiliano e o triunfo dos liberais, o que se consumou com a entrada de Benito Juarez na Cidade do México, em 15 de junho. Uma das principais medidas de Juarez foi pacificar o país, principalmente, reduzindo o contingente militar. Outra medida importante foi a convocatória, em 18 de agosto, para as eleições. Conhecida como Convocatória para a eleição dos supremos poderes federais, conclamava o povo mexicano para que, segundo o artigo $1^{\circ}$, “[...] baseado na lei orgânica eleitoral de 12 de fevereiro de 1857, proceda às eleições de deputados ao Congresso da União, de presidente da República e de presidente e magistrados da Corte Suprema de Justiça" (RAMÍREZ, 1978, p. 684). Contudo, essas eleições foram marcadas por uma indiferença da massa da população, abstendo-se de votar nas eleições primárias de 22 de setembro. Ocorridas as eleições secundárias, Juarez foi reeleito presidente e formou-se uma Câmara de Deputados e uma Suprema Corte de Justiça.

No quadro dos principais liberais que compunham o novo governo (conhecido como los treinta), havia dois setores: o dos civis, que na maioria eram cultos e urbanos, e o dos militares, de origem majoritariamente popular e mantinha ora uma posição conservadora ora uma posição liberal. O projeto liberal foi elaborado pelos dezoito liberais da "ala civil" e visava a construir um Estado-Nação homogêneo e importante no sistema internacional.

Assim que assumiu o governo em 1867, Juarez tomou uma medida no sentido de reorganizar, refazer e disciplinar melhor o Exército, que era minado pelas ambições dos chefes e envolviase nas lutas políticas dos Estados, nos quais "[...] havia um grupo sempre disposto a arrancar pela violência do poder e da caixa do erário o grupo dominante" (SIERRA, 1950, p. 72-73). Neste sentido, o governo reduziu " [...] o Exército a cinco divisões de quatro mil homens cada uma, ficando, assim, licenciados outros tantos soldados, chefes e oficiais" (VILLEGAS, 1977, p. 121). O Exército teve os seus quadros aos poucos reduzidos, porém pesava contra a pacificação do país a ânsia contínua de poder dos militares o fato de milhares de mexicanos, sem muitas condições de sobrevivência, viverem da bandidagem, e o intuito de se buscar a autonomia 
por parte de algumas sociedades locais. A segurança interna era vista pelo governo como uma forma de se garantir a existência da federação, isto é, para "[...] fortalecer os laços que deveriam existir entre os Estados e o governo federal porque os bandoleiros não só constituíam uma verdadeira praga para os habitantes, mas também porque a insegurança era um obstáculo para a afluência de capital ao país" (SCHOLES, 1972, p. 72-73).

Outro fator que impedia a pacificação do país era o caudilhismo e os levantes. Os levantes ocorriam baseados no rompimento com o governo federal a partir da ideia, de acordo com Antonio Annino, “da ordem 'natural' da não, de sua pré-existência ao Estado, de sua soberania delegável só mediante um pacto temporário e nunca definitivo" (ANNINO, 1999, p. 81). Desse modo, os poderes locais, exigindo a sua soberania, rompiam com o governo central e decidiam sobre o apoio a um levante, embora as constituições do país estabelecessem a natureza administrativa dos ayuntamientos. Acreditava-se na ideia da nação enquanto estado natural, anterior e autossuficiente frente ao Estado.

A soberania dos Municípios revelava uma herança colonial que questionava a obediência à constituição federal e a legitimidade do governo federal e do Congresso Nacional, mas também uma cultura política que era marcada pela duração no tempo e que não poderia ser mudada de um momento para outro. A insistência dos poderes locais em afirmarem a sua soberania frente ao poder central deviase a uma cultura política de questionamentos da legitimidade da ação deste no sentido de retirar parte da autossuficiência daquele. Os questionamentos dos municípios diante da possibilidade de perderem a sua "soberania" eram os seguintes:

De quem era a república? De todos os cidadãos da nação ou daqueles que já controlavam com os seus municípios eletivos os territórios, administrando uma justiça própria segundo os costumes imemoráveis? Se a república não oferecia mais liberdade e autogoverno que aqueles já obtidos antes pelas cidades, onde se estabelecia, então, a legitimidade dos gover nantes? Por quê se requeria obedecer às suas leis? Problemas de difícil solução, encravados nas ambivalências de uma 
linguagem oficial que durante todo o século proclamou que a soberania estava no povo, mas também nos pueblos. Constituições, planos, opúsculos e diários reproduziriam e difundiriam constantemente esta dupla definição, e não é fácil compreender por quê as classes dirigentes a aceitaram. Uma explicação possível é que o termo soberania de los pueblos apresentava uma forte carga de legitimidade histórica, uma vez que durante três séculos tinha sido parte da América de linguagem imperial. (ANNINO, 1999, p. 86).

O caudilhismo também era um obstáculo à pacificação do país e tinha origem na estrutura vice-reinal, sendo, portanto, uma herança colonial. De acordo com Roderic Ai Camp,

[...] os vice-reis individuais chegaram a ser extremamente importantes, pois alguns ocuparam o cargo por muitos anos, completamente a capricho da Coroa. Isto deslocou consideravelmente a legitimação política das instituições espanholas para o indivíduo (CAMP, 1995, p. 41).

Surgiu, assim, uma das marcas do fenômeno político denominado caudilhismo, que é o personalismo, isto é, a autoridade política passa a ser centrada não no cargo ocupado, o que conduziria à institucionalização da estrutura administrativa, mas na figura de um indivíduo. Esse indivíduo não tem praticamente limites à sua tomada de decisões. Por outro lado, para se manterem no poder, os caudilhos necessitavam do apoio de um grupo armado. Daí a relação entre eles e uma parte do Exército, que em troca do apoio exigia a manutenção de seus privilégios. Dessa forma, estabeleceuse uma "[...] estreita vinculação entre os militares e as autoridades civis, com as linhas de subordinação pouco claras, que fizeram que as distinções se tornassem apagadas nas relações entre civis e militares" (CAMP, 1995, p. 39-40).

Outro aspecto que explicava o caudilhismo era a falta de integração entre as diversas regiões do México por causa da carência de comunicações e transportes. Isso ocasionava a existência de interesses estritamente locais e dos caudilhos que não tinham vínculo nenhum 
com o governo federal. Portanto, a população local desenvolveu laços com os caudilhos, não com as autoridades centrais, por meio de relações paternalistas que, no terreno político, segundo Roderic Ai Camp, "[...] geralmente se traduzem em que a quem conheces é mais importante que o que sabes" (CAMP, 1995, p. 44).

Durante a República Liberal Restaurada, o operariado era uma pequena parcela da população mexicana e estava vinculada ao setor fabril, que se encontrava nas principais cidades do país. De acordo com Francisco López Cámara,

[...] a maioria do proletariado mexicano repartia-se entre os dois setores operários mais importantes do país: os trabalhadores das minas e os operários das fábricas e manufaturas. Havia, por fim, um terceiro setor importante: o dos artesãos tradicionais, que representavam a transição entre as classes camponesas e o proletariado propriamente dito. (CÁMARA, 1973, p. 223).

A liberdade de associação colaborou para o surgimento de várias sociedades de trabalhadores, sendo que a primeira a surgir foi a Sociedad de Trabajadores Mineros de Zacatecas, em 1969. As sociedades de trabalhadores eram organismos de defesa que objetivaram a aliança entre os trabalhadores no sentido de se desenvolver uma solidariedade na exigência por melhores condições de trabalho e subsistência, como melhores salários e elevação material e intelectual dos trabalhadores.

Essas sociedades foram agrupadas em $1872 \mathrm{em}$ torno do Gran Círculo de Obreros de México, cujas lideranças apresentavam ideologicamente princípios liberais combinados com orientações socialistas. É importante observar que o Gran Círculo de Obreros de México, além de propor programas de instrução dos operários (apoiados pelo governo federal), também defendia a necessidade de uma relação harmônica entre o trabalho e o capital, em que deveria se prevalecer a negociação e a greve seria o último recurso. Foi a partir de 1867 que começaram a ocorrer as primeiras greves reivindicando, entre outros pontos, a redução da jornada de trabalho, que no caso dos estabelecimentos industriais chegava, segundo Francisco Lopes 
Cámara, “[...] a 15 horas por dia e os operários começavam sua tarefa às $6 \mathrm{da}$ manhã e não as suspendiam antes das 9 e meia da noite, com uma hora somente para comer" (CÁMARA, 1973, p. 223).

O desenvolvimento da educação era algo primordial, pois os liberais, após a vitória em 1867, passaram de uma etapa de ideias combativas a uma outra em que se necessitava estabelecer uma ordem. Os liberais precisavam no novo momento de ideias contrarrevolucionárias, mas sem cair, ao mesmo tempo, no ideário dos conservadores, ou seja, tinham que conciliar ordem e progresso.

Essa função coube ao positivismo, que foi trazido para o México por Gabino Barreda. A ideia de Gabino Barreda era preparar os futuros dirigentes da nação, tornando o positivismo um plano de política nacional. Entretanto, é importante notar-se que o positivismo não era uma teoria política. Foi a elite governante do México que se apropriou dos postulados do positivismo para desenvolver um novo conceito: a política científica. Segundo a filosofia de Comte, o positivismo era uma teoria do conhecimento, na qual o método científico era a forma de se estudar e entender o homem, baseando-se na ênfase, na observação, nos experimentos e, também, nas leis de fenômenos e na relação deles.

A partir dessa concepção, a elite governante pensou a política também como uma "ciência experimental", ou seja, "[...] os estadistas já não deviam guiar-se por teorias abstratas e fórmulas jurídicas, que não tinham feito mais que provocar revoluções e desordem. Agora tinham que se guiar pela observação, investigação paciente e experiência" (HALE, 1991, p. 18).

Caberia ao novo modelo educacional formar essa elite governante e também contribuir para que os mexicanos, de forma geral, "[...] ficassem conscientes da necessidade de que existisse uma ordem material para que assim não se obstacularizasse o trabalho ordenador do Estado" (ZEA, 1990, p. 107). O liberalismo necessitava de uma ideologia de ordem, paz e progresso material, ou seja, de uma doutrina antirrevolucionária que atendesse os seus anseios de trégua à anarquia e à desordem. Essa foi o positivismo.

O positivismo comteano foi iniciado por meio da Escola Preparatória Nacional, quando Gabino Barreda assumiu a sua direção em 1868. O positivismo defendia a necessidade de estudar a 
sociedade por meio de análises científicas. As duas grandes medidas tomadas por Barreda foram a implantação do ensino elementar obrigatório e a reformulação do ensino superior.

A implantação do ensino elementar obrigatório era importante porque acabava com a ignorância, vista por Barreda como "[...] o principal ou mais poderoso impedimento que detém nosso país no caminho de seu engrandecimento" (VÁZQUEZ, 1975, p. 56). Por outro lado, a reformulação do ensino superior sustentava-se na intenção de transformar um currículo de orientação humanística e idealista em um currículo uniforme para formar as classes dirigentes, com o estudo sistemático das ciências. Objetivava-se, assim, a formação de uma ordem mental.

Os positivistas também queriam acabar com o ensino laico. Esse intuito encontrava em Comte a sua explicação, pois, para ele, os interesses da Igreja eram incompatíveis com os da burguesia e, existindo essa incompatibilidade, o claro não podia seguir sendo capaz de ordenar a sociedade. Trata-se, na realidade, do embate entre a posição da Igreja, contrária à laicidade, e o pensamento leigo que defende a emancipação dos espíritos.

Os liberais buscaram o desenvolvimento econômico do México baseado na entrada de capitais externos, cujo dinheiro possibilitaria o fomento da agricultura, da indústria e do comércio externo. Existia a necessidade de um grande fluxo de capitais na forma de investimento. Isso produziria uma expansão dos mercados locais. Por outro lado, esse desenvolvimento do mercado interno estava relacionado à existência de modernas vias de comunicação e transporte. Porém, faltava dinheiro para isso. Foi então que entrou em cena o capital estrangeiro de origem, sobretudo, inglesa, francesa e norte-americana.

Os investimentos ocorreram nos setores minerador, ferroviário e agrícola. Entretanto, apesar dos esforços dos liberais, o capital externo não investiu muito na economia mexicana, por causa do clima de instabilidade que existia no país entre 1867-1876. Consequentemente, os investimentos externos ocasionaram apenas o progresso de certos ramos da economia, com destaque para a mineração (extração de ouro e prata). Depois do processo de independência, a mineração apresentou uma queda na produção devido à falta de 
verbas. Ao mesmo tempo, o capital privado nacional não investia muito na mineração por ser um setor com rentabilidade a longo prazo. Desse modo, coube ao capital externo a retomada efetiva da atividade mineradora, o que é explicado pelo fato de que

[...] os países europeus mais desenvolvidos, e aos poucos também os Estados Unidos, graças aos progressos técnicos obtidos na indústria e aos altos lucros alcançavam, buscavam expandir o mercado consumidor para os seus produtos e boas oportunidades para investir o capital acumulado. O financiamento da construção de ferrovias e a exploração direta de riquezas naturais do território mexicano foram parte do processo imperialista. (SOARES; COLOMBO, 1999, p. 93).

O problema da carência de vias de comunicação constituía em um dos principais obstáculos ao desenvolvimento da economia, uma vez que, aliada a questões geográficas (enormes distâncias, contrastes climáticos e relevo acidentado), impedia a circulação da produção pelo país, ficando as várias regiões restritas a uma produção e um consumo local. Para solucionar tal problema, realizaram-se contratos com empresas privadas, sob a supervisão do governo federal, para a construção de ferrovias, unindo a capital com os principais mercados e portos do México. Além disso, instalaram-se linhas telegráficas.

Procurou-se também superar um dos maiores obstáculos ao desenvolvimento do comércio, que era a anarquia fiscal. Para isso, foram adotadas medidas importantes como:

[...] combinar as distintas taxas sobre mercadoria importada em uma só e fixar os direitos de importação em uma quantidade determinada, usando uma base ad valorem só naqueles casos onde não pudesse fixar-se uma quota específica; abolição da lista de proibições e aumento da de artigos livres; abolição de restrições onerosas sobre a circulação interna de mercadorias estrangeiras que já haviam pago direitos de importação; estabelecimento do sistema métrico decimal e; autorização para exportação de metais preciosos em barras. (SCHOLES, 1972, p. 223-224).

Anos 90, Porto Alegre, v. 18, n. 34, p. 361-393, dez. 2011 
A anarquia fiscal era ocasionada por inúmeros decretos fiscais promulgados nos Estados. Porém, o excessivo número de impostos não representava uma grande arrecadação, pois não havia uma organização administrativa eficaz. A consequência da anarquia fiscal era o contrabando que se valia da ausência de controle sobre as aduanas.

Quanto à secularização, os liberais adotaram as seguintes medidas: a separação entre a Igreja e o Estado; o fim das comunidades religiosas, tornando-se associações ilegais; a proibição à aquisição de bens imóveis por parte das corporações e; mudanças no estado civil das pessoas e nas manifestações externas do culto.

O processo de secularização era uma tentativa de se superar, por causa da instabilidade política, uma prática dos governos e de seus adversários de utilizar o sagrado para reforçar um poder central fraco e com isso se legitimar. Além disso, o processo de secularização inseria-se em uma luta pelo estabelecimento do que Walter V. Scholes chama de "capitalismo democrático" por meio do despojo das propriedades da Igreja e de seus privilégios especiais e do estabelecimento da tolerância religiosa.

Os liberais tinham em vista que o Estado, e não a Igreja, deveria ser o autêntico governo. A Igreja com o seu poder e os seus privilégios era percebida como um obstáculo ao progresso da nação. Daí a necessidade de se reformar o clero. De acordo com os liberais, o clero tinha esquecido a sua missão espiritual, preocupando-se mais com as suas riquezas. A secularização era uma garantia de estabilidade e da liberdade de que tanto o país necessitava. Somente assim poder-se-ia conseguir a submissão do clero em questões temporais ao Estado, dedicando-se exclusivamente à sua missão sagrada.

A Igreja mexicana resistia ao governo liberal desde os templos, em que, por causa de sua influência na maioria das mentes dos mexicanos, incentivava revoltas em todo o país. De acordo com os liberais, a solução para tal problema era formar uma nova consciência nos mexicanos, o que só seria possível substituindo os preceitos da religião católica por outros em suas mentes. Esses outros preceitos viriam do positivismo, que pregava a emancipação da consciência e, consequentemente, a oposição à religião católica, uma vez que era 
[...] uma força negativa que se opunha a deixar um posto no qual já não possuía missão alguma. A ordem predicada pelo clero não era a ordem que correspondia à etapa do progresso em que a humanidade encontrava-se. Era necessária a ordem, mas a ordem tinha que ser o que os positivistas chamavam positiva. A revolução triunfante encarnava as forças desta ordem. (ZEA, 1990, p. 65-66).

Assim, o objetivo era destituir o catolicismo como instrumento político, uma vez que era impossível descatolizar o México. Daí a importância do processo de secularização e do positivismo nele. $\mathrm{O}$ primeiro passo a ser dado deveria ser no sentido do fim do ensino subordinado à Igreja. Esse intuito encontrava em Comte a sua explicação, pois, para ele, os interesses da Igreja eram incompatíveis com os da burguesia e, existindo essa incompatibilidade, tal instituição não podia seguir sendo capaz de ordenar a sociedade.

\section{José Martí e a interpretação do projeto liberal mexicano para a construção do Estado-Nação}

O projeto liberal para a construção do Estado-Nação constituiu o principal elemento de análise nos artigos escritos por Martí no México. $\mathrm{O}$ interesse de Martí era perceber a influência desse projeto no cotidiano. A passagem de Martí pelo México foi importante para a sua formação intelectual porque, como afirma Nelson Martínez Díaz,

[...] desde esse país, Martí começa a perceber o pulso da América. Depois de tudo, a situação social, uma palpável marginalização do índio, a corrupção que impregnava alguns círculos e a precariedade de toda política progressista levada desde os governos, sempre perseguidos pelos poderes fáticos ou pela ameaça do expansionismo das potências que representavam nesse país o drama do que logo chamaria de Nuestra América. (DÍAZ, 1992, p. 42). 
Portanto, os artigos escritos por Martí no México são importantes para a compreensão de seu pensamento. Pode-se perceber também, a partir desta perspectiva, a repercussão da realidade mexicana no pensamento martiano.

O ponto central para a compreensão da influência da realidade mexicana no pensamento de José Martí é o projeto liberal, pois vários aspectos desse projeto são abordados nos artigos do intelectual cubano. É essencial, portanto, confrontar as ideias liberais com a visão martiana do México. Isso possibilita perceber o grau de repercussão das ideias liberais no pensamento de Martí.

Entretanto, por outro lado, não se pode compreender o pensamento de José Martí como um mero receptáculo das ideias liberais existentes no México e influenciado pela realidade desse país. Do mesmo modo em que isso ocorreu, houve também a perspectiva, por parte de Martí, de se utilizar das ideias em voga e das observações feitas por ele sobre a realidade mexicana por meio de seus artigos com o fim de informar a sociedade sobre os desafios enfrentados e as conquistas alcançadas pelo México. Em outras palavras, a sua contribuição para a transformação do contexto histórico far-se-ia por meio da informação e da conscientização dos indivíduos ao exercer o seu ofício de periodista. Por isso, para Martí, a imprensa deve transmitir ao povo a conjuntura nacional e sugerir para este formas de defesa de seus direitos e de obtenção de prosperidade.

A imprensa deve contribuir para o estabelecimento da ordem e para a solução dos problemas nacionais por meio de suas análises da realidade, apontando as questões que merecem um exame e uma resolução imediatas por parte do governo. Para Martí,

[...] tem a imprensa periódica altíssimas missões; é uma a de explicar na paz e na luta fortalecer e aconselhar; é a outra fazer estudo das graves necessidades do país, fundar as suas melhoras, facilitar assim a obra à administração que rege, e uma vez que tantas graves questões preocupam em uma nação que ascende de uma situação vacilante e anômala à de terra dona de si e livre, ajude a imprensa periódica aos que governam, assinalando e apresentando estudadas as questões que têm necessidade mais séria e vigente de reforma. (MARTÍ, 1963, p. 263). 
O principal obstáculo ao estabelecimento da ordem no México era o caudilhismo. A partir dessa observação, Martí caracteriza esse fenômeno pela busca incessante do caudilho ao poder político com o objetivo de obter benesses imediatas por meio da colaboração de aliados vinculados a relações clientelares.

$\mathrm{Na}$ perspectiva martiana, os interesses da nação são prejudicados ao se lançar o país em guerras internas que apenas provocam a desordem e impedem o progresso necessário. A partir desse entendimento, Martí faz o seguinte questionamento sobre a razão das guerras internas: "Depois do estouro, dos infernais gritos, da matança bárbara, das sangrentas ondas, flutuará só sobre o mar de obscura púrpura um homem triunfador e sorridente, feliz estátua em pedestal de mexicanos?” (MARTí, 1963, p. 360).

A partir do repúdio ao militarismo e ao caudilhismo enquanto fatores de desordem e atraso, o intelectual cubano defende o fim das guerras internas, afirmando que

[...] o México é um povo livre, trabalhador e pacífico; estas lutas nos cansam; esse militarismo nos irrita; essa falta de respeito à pátria exalta a nossa indignação. Temos leis feitas, caminhos preciosos, vias diretas para vir ao Governo da Pátria; como os grandes afetos, o nosso amor à lei não se tem feito sentir senão no pensamento em que a temos visto desrespeitada e vulnerável; cada homem é um sacerdote dessa religião que não temos querido respeitar. (MARTÍ, 1963 , p. 360).

Martí, enquanto defensor do governo civil democrático que emana da vontade do povo, vê no caudilhismo a ameaça para a democracia, pois os caudilhos eregem como chefes supremos do Estado, não sendo funcionários da nação a serviço dos interesses gerais, mas donos do poder e a favor de interesses pessoais.

Com relação à meta da liberdade de associação e trabalho do projeto liberal, Martí é totalmente favorável, defendendo a organização do proletariado como a forma de se despertar a sua consciência.

Martí concebe as greves como uma mobilização necessária para que os trabalhadores possam unir-se contra a exploração indevida 
deles por parte dos patrões e por melhores condições de vida e trabalho. Isso é uma demonstração da consciência, pois os trabalhadores começam a conhecer o seu valor. Entretanto, a mobilização deve ocorrer dentro do domínio respeitável da justiça e da razão, ou seja, se, por um lado, a explicação para as desavenças na relação capital-trabalho está na exploração do operário pelo empresário, por outro, essas desavenças não devem levar ao ódio ao capital, uma vez que, segundo Martí, “[...] o direito do operário não pode ser nunca o ódio ao capital: é a harmonia, a conciliação, a aproximação comum de um e de outro" (MARTí, 1963, p. 275). Portanto, defende o direito à greve como uma forma de defesa pacífica dos direitos dos trabalhadores, não enquanto um fator que incite as tensões formais.

A luta contra a opressão deve ser pacífica, uma vez que Martí era contrário à revolução. Martí, influenciado pela ideia da necessidade de estabelecimento de uma ordem por parte dos liberais, é a favor de um progresso social baseado em uma evolução harmônica. Os trabalhadores devem buscar os seus direitos dentro da sensatez.

Para que os operários saibam buscar os seus direitos dentro da sensatez, é preciso educá-los e conscientizá-los dentro de princípios sãos e severos. Desse modo, para Martí, os trabalhadores perceberão que é um erro pensar que "[...] a sua liberdade consiste em exercer um domínio vingativo sobre os seus patrões, predicando a doutrina da digna conciliação” (MARTí, 1963, p. 346). São de suma importância nesse sentido os periódicos e as reuniões de trabalhadores como uma forma de examinarem a sua situação, buscando o bem-estar e a convivência harmônica com o capital.

Martí dá uma grande ênfase ao papel das organizações trabalhistas, pois, por meio delas, os trabalhadores podem lutar contra a opressão. Essas organizações constituem os meios pelos quais os trabalhadores se unem em uma fraternidade por objetivos comuns. Para Martí, tal fraternidade,

[...] não é uma concessão, é um dever. Quando padecem os artesãos trabalhadores; quando em apoio de um princípio justo empreendem uma luta enérgica a que não estão acostumados e que não têm meios materiais para sustentar; quando a fraternidade estende a mão em apoio de uma ideia 
nobre e justa, muita severa reprovação merecem aqueles que viram os olhos da mão necessitada e estimulante que têm os operários para com os irmãos sem trabalho e que se fechado sem que os operários ponham nela o seu óbolo simples, mais valioso pela força da união que tivesse representado que pelos resultados práticos que a modesta quantidade tivesse podido produzir. (MARTÍ, 1963, p. 227-228).

Martí acreditava que o desenvolvimento da educação no México era uma das principais ideias do projeto liberal.

A educação era a forma de tornar o indivíduo informado sobre a realidade, tornando-os capazes de perceberem os problemas que atingem o país e que impedem o seu desenvolvimento. Também é o meio necessário para a formação de cidadãos conscientes de seu papel social de colaboradores na construção de um Estado-Nação mexicano. Entretanto, antes dessa conscientização, era fundamental que o povo se tornasse livre por meio dos saberes culturais adquiridos na escola, uma vez que a ignorância era o grilhão que prendia o indivíduo à opressão. Para Martí, é somente com a educação que o indivíduo se torna independente e adquire dignidade. Como a pátria mexicana era formada pelo conjunto de indivíduos que a compunha, a independência e a dignidade deles representava a independência e a dignidade da própria pátria, pois, para José Martí,

[...] um povo não é uma massa de criaturas miseráveis e regidas; não tem o direito de ser respeitado até que não tenha a consciência de ser regente; eduquem-se nos homens os conceitos de independência e própria dignidade; é o organismo humano compêndio do organismo nacional; assim não haverá logo a obrigação do estímulo para a defesa da dignidade e da independência da pátria. (MARTÍ, 1963, p. 311).

A liberdade que possibilitaria a dignidade e a independência. Entretanto, a tarefa da educação no sentido de garantir a liberdade do povo não é fácil pelo fato de que "[...] é a educação o estudo que o homem põe em guiar as suas forças; tanto mais trabalhosa 
será a sua obra quanto sejam potentes e rebeldes as forças que quer conduzir e encaminhar" (MARTÍ, 1963, p. 254).

Para Martí, a educação pública deveria ser regida por dois princípios básicos: a obrigatoriedade e a liberdade de ensino. Acima de tudo está o primeiro princípio, porque "[...] aquela tirania saudável vele ainda mais que esta liberdade" (MARTÍ, 1963, p. 351). A liberdade está subordinada a ele, uma vez que

[...] quando todos os homens souberem ler, todos os homens saberão votar, e, como a ignorância é a garantia dos extravios políticos, a consciência própria e o orgulho da independência garantem o bom exercício da liberdade. Aos artigos de fé do dogma católico tem substituído os ensinos da razão. O ensino obrigatório é um artigo de fé do novo dogma. (MARTÍ, 1963, p. 351-352).

Martí apoia em parte o projeto liberal no que se refere à modernização do México. Ele afirma que os principais problemas econômicos do México são a dependência de uma economia mineradora, a falta de incentivos para o desenvolvimento da indústria nacional, a entrada em excesso de produtos estrangeiros e uma agricultura atrasada.

A respeito da adoção de uma política protecionista ou de livre comércio, Martí defende que a escolha por uma dessas políticas deve seguir dois princípios. O primeiro deles é que "[...] os interesses criados são respeitáveis enquanto que a conservação destes interesses não prejudica à grande massa comum". O outro é que "[...] é preferível o bem de muitos à opulência de poucos" (MARTÍ, 1963, p. 346). Portanto, a escolha entre um sistema protecionista ou de um de livre comércio deve levar em conta, a partir da análise das circunstâncias, aquele que gere a maior soma de bens.

O intelectual cubano concorda com as metas econômicas do projeto liberal para a construção do Estado-Nação aspirado: o fomento da agricultura, da indústria, do comércio externo e da mineração. Contudo, nem sempre concorda com a maneira como se pretende atingir essas metas. Além disso, está convicto da potencialidade mexicana. 
Segundo Martí, a economia mexicana não poderia depender praticamente da mineração para sobreviver, mas também investir em outros setores, como a agricultura, a indústria e o comércio, que possibilitam uma geração de riquezas mais constante e melhor distribuída. Para Martí, o problema da mineração é que

[...] nas minas, espécie de trabalho de azar, sujeito a contínuas mudanças e incidentes, aproveitam os produtos poucos, estancando a riqueza e aumentando o desequilíbrio econômico das fortunas mexicanas: excessivamente ricos uns e excessivamente pobres outros. Como se vê, este desequilibrio não redunda em benefício da nação: a cidade onde há muitos ricos é, contudo, miserável e são nela o comércio débil, as mudanças difíceis, a atmosfera densa e inextinguível o ódio que desperta nos corpos vestidos de farrapos a presença contínua dos desocupados vestidos de riquezas. (MARTÍ, 1963, p. 348).

Martí defende a necessidade de um avanço industrial para o México. No caso, o desenvolvimento da indústria nacional. Todavia, enquanto o projeto liberal pregava a abolição das restrições sobre a arrecadação de impostos do governo federal, Martí via na entrada em excesso de produtos estrangeiros a razão para a dificuldade de expansão da indústria nacional, uma vez que gerava a falta de mercado. A produção nacional não tem como concorrer com os produtos importados de países que se encontram em um estágio mais avançado de desenvolvimento industrial porque os seus produtos não têm a perfeição dos produzidos pelos países com indústrias evoluídas.

O comércio externo é conveniente e bom. Porém, é preciso que ele seja controlado pelo governo, pois

[...] abandonadas ao seu próprio esforço, morrerão as nossas indústrias por falta de mercado. Ninguém comprará o imperfeito quando tem o perfeito a mão; a esta desconsoladora e natural verdade ajuda o alto preço que se tem que pagar pelos produtos de nossas indústrias incipientes (MARTÍ, 1963, p. 269).

Anos 90, Porto Alegre, v. 18, n. 34, p. 361-393, dez. 2011 
Quanto à possibilidade do comércio externo trazer bons resultados para a indústria mexicana, era praticamente impossível porque

[...] para que o comércio seja frutífero para o México temos que ter produtos para exportar. Hoje não temos produtos em quantidade suficiente para a exportação; por isso, nosso mal-estar é tanto, dificilmente compensado com a acidental riqueza nas minas (MARTÍ, 1963, p. 349).

Deve-se, assim, possibilitar a entrada no México de produtos que esse país não pode produzir, assegurando à indústria nacional uma demanda que pelo menos cobrisse os seus gastos em investimento. Dessa forma, "[...] em pouco tempo despertariam e fomentariam centros de produção, a cujo avanço e melhoramento estão cheias a fertilíssima terra mexicana e a hábil e ainda preguiçosa inteligência de seus filhos" (MARTÍ, 1963, p. 270). Ao mesmo tempo, gerar-se-ia empregos para trabalhadores desempregados. Outro fator que pesava na posição de Martí a favor do protecionismo era a concorrência desleal com os produtos importados por causa do preço deles, que

[...] se vendem no México cinquenta por cento mais barato que os mexicanos. Há direito para obrigar à grande massa de consumidores para que compre por cinco pesos um produto mexicano quando pode comprar por dois pesos e meio um bom produto estrangeiro? (MARTÍ, 1963, p. 335).

Para Martí, é importante a entrada de capitais externos para possibilitar as condições necessárias para o desenvolvimento interno, como a construção de ferrovias para o fluxo da produção agrícola. Com os investimentos externos em infraestrutura, principalmente, em ferrovias, facilitar-se-ia a distribuição da produção dos Estados, estimulando a indústria, a agricultura e o comércio.

Além das melhorias nas vias de comunicação, o fomento da agricultura também dependia do aumento de crédito para financiar a produção, principalmente por parte do Estado para o incentivo ao 
cultivo agrícola das classes oprimidas, o que as tiraria de sua situação de apatia e de miséria e aumentaria a produção nacional.

Martí achava um absurdo que, em um país com as proporções territoriais do México e a população que possuía, houvesse fome em decorrência do consumo ser maior do que a produção de alimentos. Isto devia-se ao atraso das técnicas de produção e à falta de incentivos. A solução para o problema da fome e da baixa disponibilidade de alimentos era incentivar o homem do campo a

[...] cultivar a terra de modo em que todas as épocas produza mais do que o necessário para viver; assim se basta ao imprescindível, previne-se o fortuito e, quando o fortuito não vem, começa-se o excedente produtivo que desenvolve a verdadeira riqueza. A terra nunca decai, nem nega os seus frutos, nem resiste ao arado, nem perece; a única riqueza inacabável de um país consiste em igualar a sua produção agrícola ao seu consumo. (MARTÍ, 1963, p. 310-311).

No que diz respeito à mineração, Martí defendia o fomento de uma produção em benefício do México, ou seja, que estimulasse a riqueza nacional, pois, até então, os produtos das minas tinham servido praticamente apenas para se pagar as dívidas do país no exterior. Para ele, a riqueza gerada pela mineração mexicana

[...] começará a ser útil ao país quando possa se aplicar em benefício dele mesmo e não tenha que se levar para fora da pátria em pagamento das mais simples necessidades materiais e domésticas. As minas não são hoje um alimento da riqueza nacional; os seus produtos exportam-se em pagamento dos produtos de consumo que se importam para o México e que por sua natureza e pela atual constituição social, têm necessária renovação breve e constante. (MARTÍ, 1963, p. 168-169).

Martí posiciona-se a favor das medidas liberais contra a Igreja como a liberdade de consciência, a separação entre Igreja e Estado e a proibição da celebração de atividades religiosas fora dos templos. 
Assim como os liberais, ele acreditava que a secularização era um processo necessário porque a Igreja, enquanto associação política, era um fator de instabilidade política. O clero, ao invés de cumprir o seu papel de levar aos indivíduos valores espirituais, acabou preocupando-se apenas com poder e riqueza. Daí a importância da secularização no sentido de se garantir a estabilidade e a liberdade. Para Martí, o ponto principal para se submeter o clero nas questões temporais ao Estado era o estabelecimento da liberdade de consciência, o que possibilitaria aos mexicanos saírem do jugo da denominação da religião católica sobre as suas mentes. O intelectual cubano acreditava que a tendência natural dos homens era mais cedo ou mais tarde reagirem contra a dominação de sua consciência, pois

[...] há no ser humano uma invisível e extraordinária força de segredos, bom senso e razão, e se a religião católica desconfia de sua força, apesar de sua sobrenatural origem; se, apesar de ser divina, tem medo dos homens; se para dar ao homem a consciência; se a religião da doçura converte-se na cortesã da ambição e da força - este ser que tem livre o pensamento não quer que se faça hipócrita a sua vontade; o conceito humano rebela-se; a força comum levanta-se contra a força tirânica; a paz de todos contra a insaciável ambição de alguns; e a religião da liberdade comum e o racional arbítrio próprio contra a dominação absorvente e a fiscalização e o encadeamento de consciência. (MARTÍ, 1963, p. 226).

Segundo Martí, o momento era o de se fazer prevalecer o Estado sobre a Igreja, uma vez que ela foi responsável, por causa da sua cobiça de poder e riqueza, por muitos episódios tristes na história mexicana. Desse modo, começava-se o triunfo da liberdade de consciência em que o Estado garantia aos cidadãos a liberdade de culto. Utilizando-se de uma metáfora da bandeira e da cruz para se referir ao domínio do Estado sobre a Igreja em questões temporais, Martí afirma que

[...] as épocas cumprem-se e a consciência emancipada rega agora ao seu opressor. A bandeira da liberdade era na 
Igreja o trunfo de uma época e, ao mesmo tempo, protegia o Palácio Nacional onde reside o governante, edifício onde os governados podem exercer livremente o culto. A bandeira estava sobre a cruz porque a cruz fez-se insígnia de tirânica ambição e erros tristes. Juntas estariam se a cruz não tivesse perfurado e vendido a bandeira. (MARTí, 1963, p. 261-262).

Contudo, para que a separação entre Igreja e Estado se efetivasse, era necessário que os próprios governantes servissem de exemplo, colocando os interesses do Estado acima de seus preceitos religiosos. De acordo com José Martí,

[...] um governador pode ter simpatias íntimas por um culto determinado; porém, quando aceita o cargo de governador, muito difícil para que todos o entendam e o cumpram, aceita com ele a Constituição e as leis adicionais que o cargo representa; proíbem estas leis a contemplação predileta a culto algum; a lei não assiste aos atos religiosos porque a lei é o Estado; o Estado não pode ter princípios religiosos porque não pode se impor à consciência de seus membros, e o funcionário que o representa, que é o Estado enquanto é seu funcionário, como o Estado tem que ser indiferente, como ele não pode expressar determinada tendência religiosa; porque não cabe a atenção especial a uma naquele que tem o dever de atender de igual maneira a todas. (MARTí, 1963, p. 297).

Além disso, Martí posiciona-se favorável à proibição da celebração de atividades religiosas fora dos templos, condenando a realização de procissões nas ruas das cidades. Para ele, compete ao Estado impedir as atividades religiosas nas ruas, e as autoridades não devem ceder às pressões do clero nem das massas populares por este manipuladas, pois " [...] a energia do governante tem que crescer tanto quanto crescem a exigência e a injusta pressão do governado" (MARTÍ, 1963, p. 280). Tampouco dever-se-ia admitir que desde os altares o clero atacasse as Leis de Reforma, incitando o povo à revolta e desordem, nem ter receio para a aplicação da lei, que exige a prisão do clérigo, diante da pressão do povo. 
O estudo dos escritos de José Martí no México implica perceber as suas análises do cotidiano mexicano integradas com o pensamento liberal por meio do projeto para a construção de um Estado-Nação. Esta integração das ideias de José Martí e dos liberais mexicanos pode ser captada com o confronto entre os principais tópicos apontados pelo projeto liberal como fundamentais para a compreensão dos problemas nacionais e da construção de uma nação consolidada e desenvolvida e os principais aspectos abordados nos artigos de Martí para os periódicos Revista Universal e El Federalista. Assim, Martí, enquanto um exilado, pôde desenvolver as suas ideias à luz dos problemas e das circunstâncias vividos por ele no México. Muitas dessas ideias ele levaria consigo em sua bagagem intelectual para o resto de sua vida.

\section{Considerações finais}

Estudar os escritos de José Martí no México é perceber as suas análises do cotidiano desse país integradas com o pensamento liberal mexicano por meio do projeto para a construção de um EstadoNação sustentado em duas metas principais: a ordem e o progresso. Esta integração pode ser captada com o confronto entre os principais tópicos apontados pelo projeto liberal como fundamentais para a compreensão dos problemas nacionais e construção de uma nação consolidada e desenvolvida e os principais aspectos abordados nos artigos de Martí para os periódicos Revista Universal e El Federalista. Dessa maneira, nota-se que Martí apontava praticamente os mesmos problemas que os liberais como sendo os principais no México, como o caudilhismo, o militarismo, a interferência da Igreja em questões temporais e outros, e o caminho a ser trilhado para um futuro próspero, o que significava a adoção de iniciativas como a completa secularização, o incentivo ao desenvolvimento da indústria, do comércio e da agricultura, a difusão do ensino primário público e outras.

Ao mesmo tempo, tendo consciência do papel da imprensa para a conscientização dos indivíduos, Martí esperava que os seus artigos jornalísticos contribuíssem para que pelo menos a parte 
letrada da sociedade mexicana percebesse as principais questões que eram os obstáculos para o progresso e o seu papel como um possível agente ativo na transformação da realidade. Dessa maneira, Martí, assim como os liberais,acreditava que a realização de várias metas estabelecidas pelo projeto liberal dependia da formação de uma nova cultura política no seio da sociedade mexicana. Em outras palavras, o povo mexicano precisava tomar consciência de seu papel enquanto colaborador na transformação por meio de uma participação política mais efetiva e do respeito à ordem e às instituições políticas nacionais, principalmente as vinculadas à União enquanto uma esfera integradora das várias regiões e dos estados do país.

O México foi importante na formação das ideias de José Martí porque, embora ele tenha estabelecido contatos com Cuba e na Espanha com liberais e com princípios do liberalismo, foi naquele país que pôde perceber tais princípios sendo postos em prática em uma nação independente da Hispano-América. Desse modo, enxergou claramente os alcances e os limites para a aplicação das ideias liberais oriundas da Europa e dos Estados Unidos,mas adaptadas às circunstâncias mexicanas,no sentido de promover uma transformação do México. Isso explica a sua postura em defender a necessidade da adoção de soluções para os problemas nacionais levando em conta a realidade particular do México,sendo contrário à simples importação e implantação de ideias exógenas.

A compreensão do pensamento de José Martí passa pela relação tripartida entre o intelectual, as ideias em circulação e a realidade. É dessa maneira que se vê inter-relacionados o pensamento de Martí, o projeto liberal e o cotidiano mexicano.Ademais,é importante frisar que o ideário martiano,assim como o de outros intelectuais não é estático.Ao contrário, desenvolve-se a medida que ocorrem as experiências de vida. Martí, enquanto um exilado, pôde desenvolver as suas ideias à luz dos problemas e das circunstâncias vividos por ele no México. Assim, ideias e contexto histórico se apoiam e se configuram mutuamente, pois o contexto faz brotar ideias e, simultaneamente, estas fecundam aquele por meio de atos. Tem-se desenhado, então, o quadro teórico que permite entender como se deu a assimilação de ideias por José Martí no México, muitas das quais é possível que tenha levado consigo em sua bagagem intelectual para o resto de sua vida.

Anos 90, Porto Alegre, v. 18, n. 34, p. 361-393, dez. 2011 


\section{JOSÉ MARTÍ AND THE LIBERALISM: THE INTELLECTUAL TRAJECTORY OF A CUBAN EXILE IN MEXICO}

Abstract: This article presents the analysis of José Martí about the project for the construction of a Nation-State elaborated by the liberals, that it is the result of a whole of ideas that it appears and grows along the century XIX in Mexico. Of this it sorts things out, the Cuban intellectual, from his journalistic articles written during the period in that he separated at that country, among 1875 and 1876, not only left his impressions about several aspects of the Mexican daily, but also thought the reaches and the limits of the liberal project in the sense of transforming that reality.

Keywords: Nation-State. Liberalism. Mexico.

\section{Referências}

ALONSO, Ângela. Ideias em movimento: a geração de 1870 na crise do Brasil Império. São Paulo: Paz e Terra, 2002.

ANNINO, Antonio. Ciudadanía "versus" gobernabilidad republicana en México: los orígenes de un dilema. In: SABATO, Hilda (Coord.). Ciudadanía politica y formación de las naciones: perspectivas históricas de América Latina. México: Fideicomiso Historia de las Américas; El Colegio de México; Fondo de Cultura Económica, 1999 (Serie Estudios), p. 62-93.

CÁMARA, Francisco López. La estructura económica y social de México en la época de la Reforma. 2. ed. México: Siglo XXI, 1973.

CAMP, Roderic Ai. La politica en México. México: Siglo XXI, 1995.

CARVALHO, Maria Alice Rezende de. O quinto século: André Rebouças e a construção do Brasil. Rio de Janeiro: Revan, 1998.

DÍAZ, Nelson Martínez. José Martí. Madrid: Historia 16; Quorum, 1992 (Colección Protagonistas de América).

FERNANDES, Florestan. A contestação necessária. São Paulo: Ática, 1995.

HALE, Charles A. Ideas políticas y sociales en América Latina, 1870-1930. In: BETHELL, Leslie (Coord.). Historia de América Latina. Tradução de Jordi Beltrán y Àngels Solà. Barcelona: Crítica, 1991, v. 8, p. 1-64.

HEROLES, Jesús Reyes. El liberalismo mexicano. 2. ed. México: Fondo de Cultura Económica, 1974, v. III. 
MARTÍ, José. Obras completas. La Habana: Editorial Nacional de Cuba; Editora del Consejo de Universidades, 1963, t. 6.

RAMÍREZ, Felipe Iena. Leyes fundamentales de México, 1808-1973. 5. ed. México: Porrúa, 1978.

SCHOLES, Walter V. Política mexicana durante el régimen de Juárez, 1855-1872. México: Fondo de Cultura Económica, 1972.

SIERRA, Justo. Evolución politica del pueblo mexicano. México: Fondo de Cultura Económica, 1950.

SOARES, Gabriela Pellegrino; COLOMBO, Sylvia. Reforma liberal e lutas camponesas na América Latina: México e Peru nas últimas décadas do século XIX e princípios do século XX. São Paulo: Humanitas FFLCH; USP, 1999 (História: Textos de Apoio 3).

VÁSQUEZ, Josefina Zoraida. Liberales y conservadores en México: diferencias y similitudes. Estudios interdisciplinarios de América Latina y el Caribe, Tel Aviv, Universidad de Tel Aviv, v. 8, n. 1, p. 19-39, enero/junio de 1997.

Recebido em: 08/07/2009

Aprovado em: 28/02/2010 